University of Nebraska - Lincoln

DigitalCommons@University of Nebraska - Lincoln

April 2007

\title{
The successful eradication of introduced roof rats (Rattus rattus) from Buck Island using diphacinone, followed by an irruption of house mice (Mus musculus)
}

\author{
Gary W. Witmer \\ USDA-APHIS-Wildlife Services, gary.w.witmer@usda.gov \\ Frank Boyd \\ USDA-APHIS-Wildlife Services \\ Zandy Hillis-Starr \\ USDAWildlife Services
}

Follow this and additional works at: https://digitalcommons.unl.edu/icwdm_usdanwrc

Part of the Environmental Sciences Commons

Witmer, Gary W.; Boyd, Frank; and Hillis-Starr, Zandy, "The successful eradication of introduced roof rats (Rattus rattus) from Buck Island using diphacinone, followed by an irruption of house mice (Mus musculus)" (2007). USDA National Wildlife Research Center - Staff Publications. 674.

https://digitalcommons.unl.edu/icwdm_usdanwrc/674

This Article is brought to you for free and open access by the U.S. Department of Agriculture: Animal and Plant Health Inspection Service at DigitalCommons@University of Nebraska - Lincoln. It has been accepted for inclusion in USDA National Wildlife Research Center - Staff Publications by an authorized administrator of DigitalCommons@University of Nebraska - Lincoln. 


\title{
The successful eradication of introduced roof rats (Rattus rattus) from Buck Island using diphacinone, followed by an irruption of house mice (Mus musculus)
}

\author{
Gary W. Witmer ${ }^{\mathrm{A}, \mathrm{D}}$, Frank Boyd $d^{\mathrm{B}}$ and Zandy Hillis-Starr ${ }^{\mathrm{C}}$ \\ A USDA National Wildlife Research Center, 4101 Laporte Avenue, \\ ${ }^{B}$ Fort Collins, CO 80521-2154, USA. \\ CUSDA Wildlife Services, Extension Hall, Room 118, Auburn University, Auburn, AL 36849-5656, USA. \\ DChristiansted National Historic Site and Buck Island Reef National Monument, 2100 Church Street \#100, \\ Danish Custom's House, Kings Wharf, St Croix, US Virgin Islands 00821, USA. \\ ECorresponding author. Email: Gary.W.Witmer@aphis.usda.gov
}

\begin{abstract}
The United States National Park Service and the United States Wildlife Services made a planned and sustained effort to eradicate the introduced roof rats (Rattus rattus) from Buck Island Reef National Monument in the Caribbean Sea during 1998-2000. The rats were causing substantial damage to a variety of the 80-ha island's floral and faunal resources. An island-wide grid of elevated bait stations containing anticoagulant ( $0.005 \%$ diphacinone; 50 ppm) rodenticide bait blocks were used to eradicate the rats. The bait stations were modified several times to assure ready access by rats while minimising access by non-target animals, especially crabs and birds. Numerous post-project trapping sessions over six years resulted in no rat captures, suggesting that, indeed, the rats had been eradicated from the island. No non-target losses resulting from the baiting program were observed by field personnel, but they noted what appeared to be a recovery of some of the island's floral and faunal resources. There have been no depredations of endangered sea turtle nests since the eradication. Post-project monitoring sessions revealed the presence of a growing house mouse (Mus musculus) population on the island. The threats posed by, and potential management strategies for, this introduced pest species are being investigated. This is the first successful rat eradication on a sizable island, using diphacinone bait blocks with a unique, elevated bait-station system. Diphacinone can provide an alternative to the highly toxic brodifacoum and may help reduce non-target hazards in some situations, although several applications are generally required.
\end{abstract}

\section{Introduction}

Once introduced to an island, non-native rodents can cause considerable damage to the native flora and fauna, including the endangerment of endemic species (Atkinson 1985; Witmer et al. 1998). As a result, there have been numerous efforts in recent years to eradicate introduced rats (Rattus spp.) and house mice (Mus musculus) from islands around the world (e.g. Buckle and Fenn 1992; Howald et al. 1999; Billing and Harden 2000; Key and Hudson 2000; Veitch and Clout 2002; Parkes and Murphy 2003; Genovesi 2005; Lorvelec and Pascal 2005). Most of these efforts have involved the use of the anticoagulant rodenticide, brodifacoum, and in some cases, with a single application (Buckle and Fenn 1992; Innes and Barker 1999; Eason et al. 2001; Courchamp et al. 2003; Howald et al. 2005a).

Brodifacoum is a 'second-generation' anticoagulant; these were developed because of genetic resistance developed to the 'first-generation' anticoagulants such as warfarin (Hadler and Buckle 1992; Tasheva 1995). Brodifacoum and most other second-generation anticoagulants are much more toxic than first-generation anticoagulants, often killing the rodent with a single feeding (Hadler and Buckle 1992; Tasheva 1995). Concern has been expressed in various countries about the persistence of second-generation anticoagulants and the residues that accumulate in both target and non-target animal tissues with sustained use (for example, in the United Kingdom: Shore et al. 1999; in the United States: Hosea 2000; in Canada: Howald et al. 1999; in New Zealand: Murphy et al. 1998). However, residue accumulation would probably not be an issue with a single aerial-application eradication project as was performed on Anacapa Island, California (Howald et al. 2005a). Eason and Spurr (1995) provided a thorough review of the toxicity and potential impacts of brodifacoum to non-target wildlife. Hence, it has been recommended that investigators conduct field trials on the efficacy of first-generation anticoagulants, such as diphacinone, for the eradication of introduced rodents (Donlan et al. 2003). Donlan and colleagues (2003), almost simultaneously with our project, used diphacinone to successfully eradicate roof rats (Rattus rattus) from the 5-ha South Island of the San Jorge Islands off the northern Gulf of California and recommended trials on larger islands. Some of the criteria and considerations in the selection and application of a rodenticide bait for rodent control in natural settings were summarised in Witmer et al. (1998), Donlan et al. (2003) and Howald et al. (2005a). The advantages and disadvantages of the various rodenticides that can be used for rodent eradications have been discussed by Donlan et al. (2003), Howald et al. (2005b), and O'Connor and Eason (2000). 
Problems caused by introduced roof rats on Buck Island Reef National Monument (BIRNM), St Croix, United StatesVirgin Islands, have been documented by the United States National Park Service (NPS) for many years (Witmer et al. 1998). Of particular concern have been the impacts to the threatened or endangered nesting sea turtles (e.g. Eretmochelys imbricata) and the ground-nesting least tern (Sterna antillarum). Efforts to protect and to restore native vegetation (such as the lignum vitae, Guaiacum officinale) are also being hampered by rat foraging. Additionally, the NPS and the United States Fish and Wildlife Service (FWS) plan to reintroduce the endangered St Croix ground lizard (Ameiva polops) to Buck Island as part of the FWS recovery plan for that species (Furniss 1984) and rat predation poses a serious threat to lizards (Philobosin and Ruibel 1971; Meier et al. 1990). The rats also pose a human health threat to visitors to Buck Island because rats can harbour many diseases such as leptospirosis (Witmer et al. 2004) and the tick-borne relapsing fever that has been found to occur in rats from the island (Flanigan et al. 1991). An effort to control the introduced rats on the island would also increase public and territorial conservation agencies' awareness to threats from exotic pest species.

The NPS requested the assistance of the United States Wildlife Services (WS) in an evaluation of the potential for a rateradication project on Buck Island in 1998. A strategy to eliminate rats from the island was formulated and proposed (Witmer et al. 1998). In this paper, we document the successful eradication of rats on Buck Island with diphacinone (a first-generation anticoagulant) bait blocks, using a unique, elevated bait-station design project along with the recovery of natural resources, and the irruption of a suppressed house mouse population.

\section{Materials and methods}

\section{Study site}

Buck Island is part of the Buck Island Reef National Monument in the USA Virgin Islands. The island is $\sim 2.4 \mathrm{~km}$ north-east of the island of St Croix in the Caribbean Sea and comprises 80 ha, rising from sea level to $\sim 104 \mathrm{~m}$ in elevation. The island has no permanent sources of fresh water and is covered with a dry, tropical deciduous forest. The forest cover was removed for a plantation and buildings in 1754 , but the island has not been occupied by humans since the 19th century and the forest cover has recovered (Dammann and Nellis 1992). The NPS allows visitors to the island for purposes of hiking, picnicking and swimming, but does not allow overnight stays. Several species of threatened or endangered flora and fauna occur on Buck Island. Additional information on the island can be found in Witmer et al. (1998).

\section{Background preparation}

In compliance with the United States' National Environmental Policy Act, the NPS prepared an environmental assessment on the proposed rat eradication on Buck Island. It was distributed for public comment, a public hearing was held, and comments from other agencies were solicited. The received input favoured a rateradication project. The NPS issued a Finding-of-No-SignificantImpact for the environmental assessment, allowing the project to proceed (Joel Tutein, NPS Park Superintendent, pers. comm.).
Registration with the United States Environmental Protection Agency and the Virgin Islands Department of Planning and Natural Resources was obtained to use an anticoagulant rodenticide for the rat eradication. The rodenticide bait selected was the J. T. Eaton Bait Block (Twinsburg, OH; EPA Reg. No. 56-42), a large, wax bait block containing $0.005 \%$ (50 ppm) diphacinone (in both peanut butter/molasses and fish flavored varieties) that has been used in the United States for rodent control in and around buildings for many years. We chose diphacinone because of its relatively low toxicity, the lesser accumulation of residues in tissues, and because several fielduse registrations already existed (Tasheva 1995).

NPS worked with the WS team to develop a digital shoreline map of BIRNM, using global positioning system units. Using ArcView (Environmental Systems Research Institute, Inc., Redlands, CA), a $40 \mathrm{~m}$ by $40 \mathrm{~m}$ grid pattern was superimposed on this map. Each intersection point on the grid was labelled alphanumerically and became an individual bait-station location (Fig. 1). A database was created to track bait consumption, habitat and terrain conditions, and vegetation surrounding each bait station. Pending the registration for island-wide baiting, work was begun to mark and clear trails for the island-wide grid system for bait stations. Bait stations were placed along each line at intervals of $\sim 40 \mathrm{~m}$. A $40 \mathrm{~m}$ by $40 \mathrm{~m}$ grid spacing was chosen because most successful rat-eradication efforts have used grids ranging from $30 \mathrm{~m}$ by $30 \mathrm{~m}$ to $60 \mathrm{~m}$ by $60 \mathrm{~m}$ (Gregg Howald, Island Conservation and Ecology Group, Santa Cruz, $\mathrm{CA}$, unpublished database). This activity resulted in the establishment of 428 bait stations (Fig. 1). A portion of two grid lines in the north-east part of the island occurred in a very steep area (Fig. 1). Because it was considered unsafe for personnel to access those bait sites, bait blocks were thrown into those locations from corresponding stations above and/or below them.

\section{Bait applications and bait-station modifications}

Prior to cutting trails across the island, a preliminary baiting action was conducted at the shoreline sea turtle nesting habitat along the south-western portion of the island (1) because the beach and picnic areas are critical nesting area for three species of sea turtles and the NPS sought relief from rat harassment of

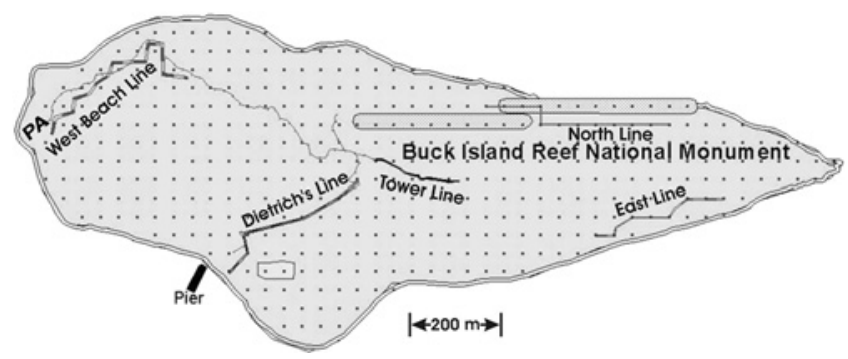

Fig. 1. Map of Buck Island, showing the location of 428 rodenticide bait stations (dots), the five rat snap-trap lines (patterned lines) used for rodent monitoring, and the steep areas (shaded ovals) that required rodenticide bait blocks to be thrown in by hand. The small circular area in the south-central part of the island is a salt pond. The letters 'PA' on the west end of the island indicate the location of the picnic area and beach. The long axis of the island runs east-west. 
female turtles attempting to lay eggs and from the predation on eggs and hatchlings that emerge, and (2) to assure that the bait blocks would be acceptable to, and effective on, the rats. Because the island-wide rodenticide registration had been requested, but not yet obtained, only the beach and picnic areas were baited. These areas were within $40 \mathrm{~m}$ of buildings or structures; such baiting was legal under an existing EPA registration (EPA Reg. No. 56-42).

This first baiting was conducted in early October 1999 (Table 1). All bait station locations along the shoreline and one tier back $(40 \mathrm{~m})$ from the shoreline were baited. Forty-four commercially available black plastic bait stations (Rodent Baiter, Bell Laboratories, Inc., Madison, WI), measuring 23 by 18 by $10 \mathrm{~cm}$ with a 6.5 by $6.5 \mathrm{~cm}$ opening in each end, were initially placed on the ground. Four bait blocks (peanut butter/molasses flavoured) were placed in each station and maintained by checking the stations every day for two weeks and every three days thereafter. After the first three days of baiting, it was apparent that hermit crabs (Coenobita clypeata) were consuming most of the bait and possibly preventing rat access. All bait stations were moved to elevated locations. Bait boxes were stapled or cable-tied to tree trunks and tree limbs $\sim 2 \mathrm{~m}$ off the ground. After two weeks of baiting, snap traps were set at or near 30 bait-station locations to determine the effectiveness of the baiting. In some cases, a snap trap was placed between two bait stations that were relatively close together rather than one snap trap at each bait station. Hurricane Lenny brought a halt to the baiting on 17 November 1999. When baiting was resumed on 3 December 1999, heavy concentrations of biting ants (Solenopsis invicta) were a problem at many of the bait stations. As a result, there was a concern that perhaps the ants were biting the rats when they attempted to access the bait and so reducing bait-take by rats. Bars of bait covered in ants were found in the bait stations and on the ground below the bait stations. This suggested that the rats had gotten to the bait, pulled it out of the boxes to get it away from the ants, and abandoned it because of the ants. All baiting was stopped at this point pending the start of an island-wide baiting program and a decision on how to control the ants. An insecticide treatment (Amdro Fire Ant Insecticide Granules, BASF Corporation, Research Triangle Park, NC; Raid Ant and Roach Insecticide Spray, SC Johnson, Racine, WI) was recommended by the NPS Integrated Pest Management Program Coordinator and used at some bait stations where there were heavy concentrations of ants during the island-wide baiting that followed. The insecticide powder was sprinkled around the base of the bait stations and did not appear to affect rats as bait was removed by rats from the treated stations.

Prior to establishing all of the bait stations, a new station mount was created to deter crabs. The plastic bait stations were elevated to $\sim 20 \mathrm{~cm}$ off the ground, using a wire platform. This system also added consistency to bait-station placement because some station locations were not near a tree or shrub to which the plastic bait station could be attached.

The first island-wide baiting was conducted on 11-21 April 2000 (Table 1). A crew of seven distributed bait to all bait stations. Three peanut butter/molasses-flavoured blocks were added to each station and replenished as needed to maintain 3 blocks per station. Bait was checked in every station every day for 10 days. The following data were collected during each bait station visit: bait consumption (which was equal to the amount of bait added), animal visitations, and treatment (insecticide, non-target interference). Initially, the crew saw signs that rats were consuming the bait: stations emptied of bait, rat faeces in the boxes, and fur on the bait station openings. The first dead rat was observed on 16 April and by Day 7, the smell of decaying carcasses was apparent throughout the island. During the 2-week 'off period', snap traps were established at every other bait station, totaling $\sim 210$ snap-traps, island-wide. One trap was always placed at each end of the grid line.

The second island-wide baiting operation was conducted during 2-14 May 2000, using two bait blocks, of the same flavour (peanut butter/molasses), per station (Table 1). A team of four conducted the baiting, dividing the island in half (north to south) with half the island's bait stations being checked each day. In the beginning of this baiting period there were signs of rats, but by the second week the evidence of rats was gone. Most of the bait was taken by hermit crabs and birds. On 11 May, a pearly-eyed thrasher (Margarops fuscatus) was observed taking bait out of a bait station. It is possible that birds may have been a bigger consumer of bait than was suspected. Prior to undertaking the final island-wide baiting, the bait station mount was again modified to reduce access by hermit crabs and other terrestrial non-targets, specifically the pearly-eyed thrasher (Fig. 2). Each bait station was affixed $25-30 \mathrm{~cm}$ above the ground to one end of a vertical steel stake $(60 \mathrm{~cm}$ long and $1 \mathrm{~cm}$ diameter) that was driven into the ground $10-15 \mathrm{~cm}$, leaving $\sim 0.5 \mathrm{~m}$ above the ground. Each box was attached to the stake in

Table 1. Rodenticide bait block applications during the Buck Island rat eradication project, 1999-2000

\begin{tabular}{|c|c|c|c|c|}
\hline Month and year & Location & $\begin{array}{l}\text { No. of bait } \\
\text { stations }\end{array}$ & Bait station placement and type & No of bait blocks (flavour) \\
\hline October 1999 (6 weeks) & Beach, picnic areas & 44 & On ground three days, then stapled to trees & 4 (peanut butter and molasses) \\
\hline April 2000 (2 weeks) & Island-wide & 428 & On wire platform, $\sim 20 \mathrm{~cm}$ above ground & 3 (peanut butter and molasses) \\
\hline May 2000 (2 weeks) & Island-wide & 428 & On wire platform, $\sim 20 \mathrm{~cm}$ above ground & 2 (peanut butter and molasses) \\
\hline June 2000 ( 2 weeks) & Island-wide & $428^{\mathrm{A}}$ & $\begin{array}{l}\text { Mounted on stake with PVC around it, } \\
\sim 25-30 \mathrm{~cm} \text { above ground }\end{array}$ & 2 (fish) \\
\hline September-October 2000 (4 weeks) & Beach, picnic areas & $52^{\mathrm{B}}$ & $\begin{array}{l}\text { On wire platform for } 2 \text { days, then on stake } \\
\text { as described above }\end{array}$ & $\begin{array}{l}2 \text { (peanut butter and molasses) } \\
\text { plus } 2 \text { (fish) }\end{array}$ \\
\hline
\end{tabular}

\footnotetext{
${ }^{\mathrm{A}}$ Includes 77 bait stations with bird excluders.
}

${ }^{B}$ Includes 26 bait stations with bird excluders. 
a vertical orientation by cable ties held in place by steel washers, which prevented the plastic box from tearing in the wind. A section of plastic polyvinyl chloride (PVC) pipe $(25 \mathrm{~cm}$ long and $6 \mathrm{~cm}$ diameter) was first placed over the steel stake. The PVC pipe, which has a smooth surface, prevented the hermit crabs from climbing up the stake and into the bait station. On stations where birds were observed to be a problem, an additional section of PVC pipe was inserted into the bait box to reduce access to the bait by birds (primarily the pearly-eyed thrasher). A length of PVC pipe $(30 \mathrm{~cm}$ long with $6 \mathrm{~cm}$ diameter) with a $9 \mathrm{~cm}$ by $6 \mathrm{~cm}$ diamond cut from the middle of its side was inserted horizontally through the bait-station access holes, leaving $4 \mathrm{~cm}$ protruding from each end (Fig. 2). This device allowed rats to jump up to the bait station and access the bait while making it very difficult for birds landing on the bait station to get into the box. Tests with captive rats showed that the rats could readily access the bait in the modified bait station with the bird-excluder device.

The final island-wide baiting was conducted during 9-22 June 2000, using these newly modified station mounts. A team of three conducted this application, dividing the island into three roughly equal areas, with the bait stations of one area checked each day. Seventy-seven stations were fitted with bird-excluder devices. A fish-flavoured bait was introduced, using two bait blocks per station (Table 1). The bait 'switch' was done so that any remaining rats that were not attracted to the original flavour (peanut butter/molasses) might be

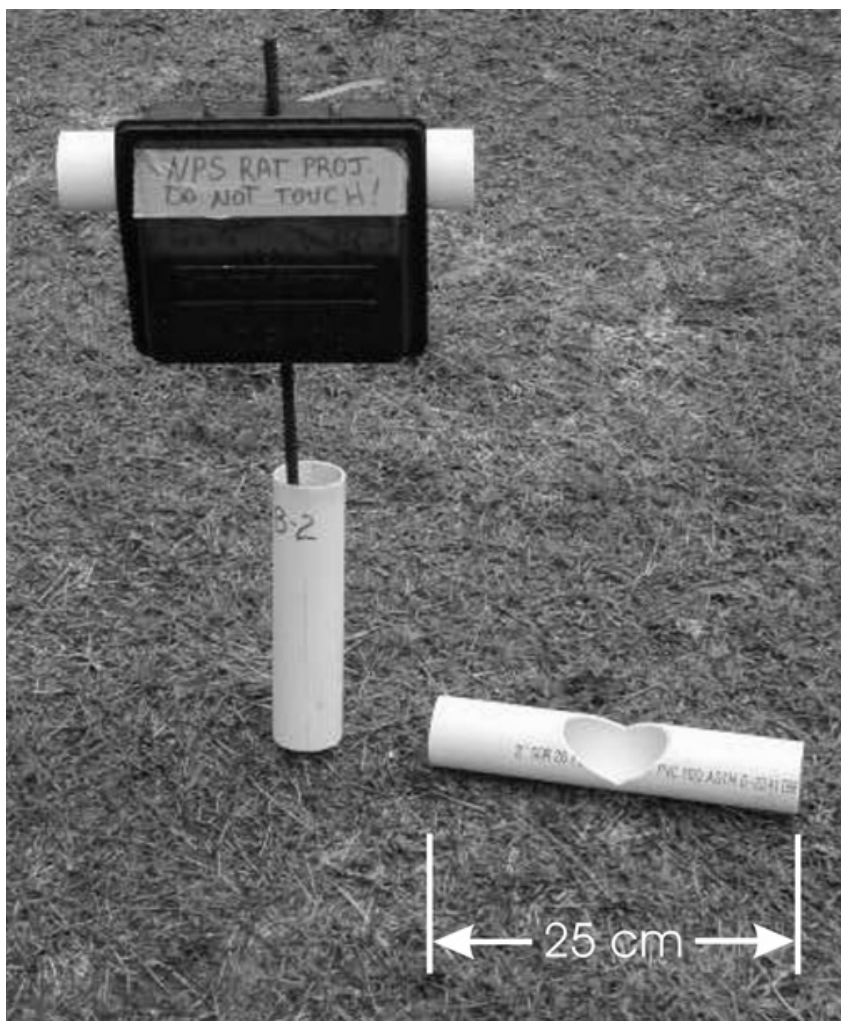

Fig. 2. The elevated rodenticide bait station (final station design) used on Buck Island, showing the 'bird excluder' insert piece. See text for description and dimensions. attracted to, and succumb to, the alternately flavoured bait block. The only bait that was consumed occurred when a baitstation lid detached and the bait fell onto the ground. It was believed that crabs then consumed the bait. On 10-13 July 2000, all bait was removed and the weight of bait remaining in each station was recorded.

During September 2000, NPS personnel monitored $1500 \mathrm{~m}$ of turtle-nesting shoreline at night. One technician momentarily observed a 'rat' near the salt pond along the south-central shore of the island. Although the sighting was not confirmed to be a rat, the original bait stations (described previously) around the beach and picnic areas were re-established along with an additional eight bait stations (for a total of 52) around the salt-pond to ensure adequate coverage where the 'rat' was observed. These bait stations were maintained with four bait blocks each (two of each flavour) until the end of October (Table 1). Initially, both platform and stake-style station mounts were used, but the platform stations were changed to stake-style stations only after a few days because of the high number of crabs observed in the platform stations. Twenty-six of the stations also included birdexcluder devices. All bait from this 'clean-up' operation was removed from the island on 15 November 2000.

\section{Rodent population monitoring}

In the original project proposal, it was strongly recommended that a rodent-monitoring protocol be designed and implemented by the NPS in perpetuity. A monitoring protocol would serve several important functions. It would assure the NPS that the rats had, indeed, been eradicated from Buck Island. It would provide a long-term, consistent, systematic source of information on any rodent populations on the island. The protocol could extend beyond rodent monitoring and include an assessment of the vegetation, noting especially any rodent damage. The monitoring protocol would provide the baseline information needed should any modification of the rodent-management program be necessary. Finally, it would give the NPS time to respond to a new reintroduction of rats to the island before the rat population became widespread and abundant, and substantial natural resource damage occurred.

The rodent population was monitored prior to eradication, during eradication, and after eradication with the use of lines of rat snap-traps. The traps were attached to the trunks of trees and shrubs $\sim 25-30 \mathrm{~cm}$ above the ground surface (primarily to reduce the captures of crabs), and spaced $\sim 5 \mathrm{~m}$ apart. Each line consisted of 15 traps. Traps were baited with peanut butter and operated for three consecutive nights. Three trap lines (D, T, W; Fig. 1) were used prior to eradication and two additional lines $(\mathrm{E}, \mathrm{N})$ were added for post-eradication monitoring.

\section{Monitoring of sea turtle nests}

Buck Island has an index nesting beach for the endangered hawksbill sea turtle. The Sea Turtle Research Program was initiated in 1988 to document sea turtle nesting activities. By 1994, nightly patrols during July-September documented rat activities. NPS had witnessed harassment of nesting hawksbill sea turtles by rats along with predation on sea turtle eggs and hatchlings. Hawksbill sea turtles are the smallest sea turtle in the Caribbean, laying 3-5 clutches every 2-3 years. Most hawksbill nests are laid in the beach forest. Their nests are shallow 
(40-44 cm) with a maximum overburden of $10-15 \mathrm{~cm}$ of sand and leaf litter. Hawksbill nests have become easy prey for the growing population of rats on Buck Island. Nesting activity and resultant nests were monitored regularly (weather permitting) from laying through hatching. Nests locations were recorded (distance to beach markers and site description), given a unique number, and tracked through to hatching. The date that the nest was laid was recorded (if observed) or estimated so that the nest could be watched closely (nightly) as the date of hatchling emergence neared. Actions by the sea turtle patrol personnel involved trapping and removing rats where they had been observed harrassing a nesting turtle or preying on nests, and relocation of nests from areas with high incidence of rat predation. If sea turtle personnel witnessed an emergence, hatchlings were protected during their crawl to the sea.

\section{Results}

\section{Bait application and non-target losses}

Diphacinone bait blocks were applied on five occasions on Buck Island over a one-year period to eradicate the introduced roof rats (Table 1). The total weight of rodenticide bait purchased for the project was $754 \mathrm{~kg}$, with $208 \mathrm{~kg}$ remaining at the end of project. Consequently, $\sim 546 \mathrm{~kg}$ of bait was applied on the island to complete the rat eradication. This amount of rodenticide bait would have contained $\sim 0.027 \mathrm{~kg}$ (=27 g) of active ingredient (diphacinone).

During the island-wide baiting operations, WS personnel spent considerable time walking the grid lines that extended over the entire island. Despite being instructed to look for them, no non-target carcasses (e.g. birds, crabs, anole lizards (Anolis acutus)) were observed by personnel during the many months of work on the island.

\section{Rat population monitoring}

Prior to bait application, rats were surveyed in February 1998, and 80 rats were captured (Table 2). Consequently, a low-to- moderate density, but healthy rat population was documented to exist on the island and substantial damage to vegetation was noted (see also Witmer et al. 1998). A final check on the rat population was conducted in August 1999, and 72 rats were captured (Table 2). These results indicated little to no change in the rat population over the six-month period.

Three surveys of the rat population were conducted during the baiting operations (Table 2). In the survey of October 1999 no rats were captured, suggesting that the bait was working to control rats along the shoreline area. In the survey of April 2000 only one rat was captured. In the survey of August 2000 no rats were captured.

After baiting operations, rats were surveyed in December 2000 , and no rats were captured, suggesting that the rat population on Buck Island had been eliminated (Table 2). Additionally, NPS and WS personnel looked for fresh sign of rat gnawing on vegetation and also for signs of active burrows. No fresh gnawing was observed and no rat droppings were found on plants or at burrows or other openings into the soil. Since that time, nine rodent surveys have been conducted and no rats have been captured (Table 2; Fig. 3). This would seem to confirm that the rat eradication was successful.

\section{Sea turtle nesting and emergence success}

Sea turtle nest success has improved substantially since the rat eradication. Hawksbill hatch success (eggs successfully hatching) averaged $70 \%$ and emergence success (hatchlings successfully leaving the nest) averaged $60 \%$ between 2001 and 2006 . Before the project, rats preyed on 10-20\% of the nests each year on Buck Island and destroyed some nests completely. Many types of rat impacts were observed. For example, during the 1994 sea turtle season, personnel observed rats sitting on top of two hawksbill sea turtles while they were digging their nests; on three occasions, rats were observed feeding on eggs as they were being laid; on 11 occasions, rats were found preying on eggs during the incubation period; and on four occasions, rats were

Table 2. Results of rat snap-trapping sessions during the Buck Island rat-eradication project, 1998-2005

\begin{tabular}{llcccc}
\hline Month and year & Location ${ }^{\mathrm{A}}$ & $\begin{array}{c}\text { No. of } \\
\text { snap traps }\end{array}$ & $\begin{array}{c}\text { No. of } \\
\text { nights }\end{array}$ & $\begin{array}{c}\text { No. of rats } \\
\text { caught }^{\mathrm{B}}\end{array}$ & $\begin{array}{c}\text { No. of mice } \\
\text { caught }^{\mathrm{B}}\end{array}$ \\
\hline February 1998 & D, T, W lines & 45 & 3 & $80(59.3)$ & 0 \\
August 1999 & D, T, W lines & 50 & 3 & $72(48.0)$ & 0 \\
October 1999 & Beach and picnic areas & 30 & 1 & 0 & 0 \\
April 2000 & Island-wide & 210 & 3 & $1(0.2)$ & 0 \\
August 2000 & D, E, N, T, W lines & 93 & 3 & 0 & 0 \\
December 2000 & D, E, N, T, W lines & 93 & 3 & 0 & $67(24.0)$ \\
April 2001 & D, E, N, T, W LINES & 93 & 3 & 0 & $103(36.9)$ \\
December 2001 & D, E, N, T, W lines & 93 & 3 & 0 & $104(37.3)$ \\
May 2002 & D, E, N, T, W lines & 93 & 3 & 0 & $31(11.1)$ \\
November 2002 & D, E, N, T, W lines & 93 & 3 & 0 & $54(19.4)$ \\
July 2003 & D, E, N, T, W lines & 93 & 3 & 0 & $43(15.4)$ \\
January 2004 & D, E, N, T, W lines & 93 & 3 & 0 & $35(12.5)$ \\
July 2004 & D, E, N, T, W lines & 93 & 3 & 0 & $27(9.7)$ \\
February 2005 & D, E, N, T, W lines & 93 & 3 & 0 & $49(17.6)$ \\
October 2005 & D, E, N, T, W lines & 93 & 3 & 0 & $36(12.9)$ \\
\hline
\end{tabular}

${ }^{\mathrm{A}}$ Code to snap-trap lines: Dietrich's $=\mathrm{D}$, East $=\mathrm{E}$, North $=\mathrm{N}$, Tower $=\mathrm{T}$, West Beach $=\mathrm{W}$.

${ }^{\mathrm{B}}$ Number in parentheses is the captures per 100 trap-nights. 


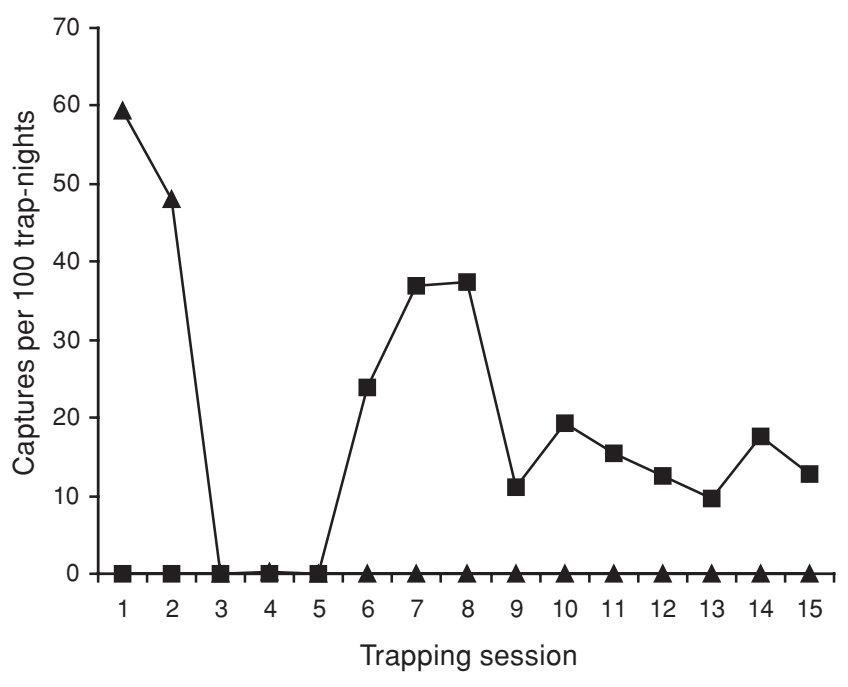

Fig. 3. Capture rates for rats (dark diamonds) and house mice (light squares) over 15 trapping sessions (see Table 2 for dates of trapping sessions). Bait application began after Trapping Session 2, followed by a rapid decline in rats to zero and an irruption and eventual stabilisation of house mice.

found preying on hatchlings upon emergence. Since the rat eradication, there has been no predation on sea turtle nests documented from 2001 through 2006.

\section{House mouse irruption}

Interestingly, during the post-eradication rodent survey of December 2000, in which no rats were captured, 67 house mice were captured (Table 2). Mice were captured on all five snaptrap lines (range $=7-31$ mice per line), suggesting an islandwide distribution. Genetic analyses confirmed that the mice were house mice (Z. Hillis-Starr, unpubl. data). We had not captured any mice previously, but an occasional house mouse had been observed on the island in past years by biologists in the course of their duties (for example, near the top of the island in 1994 (BrendaLee Phillips, USA Biological Survey, pers. comm.) and near the shoreline in 1995 (Colin Limpus, University of Queensland, pers. comm.)).

In the April 2001 rodent survey, no rats were captured but 103 house mice were captured (Table 2 ). This is $\sim 60 \%$ more than the 67 captured in December 2000, using the same trapping effort. Some fresh gnawing of woody vegetation was observed along the East trap line, presumably by mice. In addition to food, the mice may have been seeking moisture from the plants, as the weather had been very dry for an extended period. Also, the grassy habitat where the gnawing occurred provides excellent habitat for mice and this area is where the highest rate of mouse capture occurred. A similar number of mice (104) were captured in December 2001. Since that time, a lower, but relatively consistent, number of house mice have been captured during rodent surveys (Table 2; Fig. 3). This may be indicative of the mouse population having stabilised on the island.

Wildlife Services personnel conducted a brief rodenticide bait efficacy trial with some captive house mice from Buck Island during the April 2001 rodent survey. The objective of the trial was to see whether the house mice may have survived the rat-baiting operations because of a resistance to the anticoagulant (diphacinone) toxicant used in the project. This outcome with house mice was documented as a result of a sustained ratcontrol project, using the anticoagulant warfarin, on Lord Howe Island off the coast of Australia (Billing 2000; Billing and Harden 2000). In our trial, 7 of 9 (78\% mortality) treatment mice succumbed to the rodenticide bait, whereas 9 of $9(100 \%$ survival) control mice (fed a commercial rodent chow) survived the seven-day no-choice trial. The two treatment mice that survived probably would have succumbed to the toxicant within a few days as they were very lethargic and exhibited internal hemorrhaging when subjected to necropsy. This trial suggested that resistance to the bait used on Buck Island was not responsible for the survival and irruption of mice on the island.

\section{Project costs}

The eradication planning, operation, and post-eradication monitoring spanned 8 years. The total cost of the project was about US\$267700 or about $\$ 33500$ per year. About 600 person-days of effort were expended, so salaries comprised the largest single component $(69 \%)$ of project costs at $\$ 184800$. Equipment and supplies cost $\$ 38300$ which includes $\$ 7500$ for the rodenticide bait. Travel and transport costs were $\$ 24600$ and administrative overhead costs were $\$ 20000$. We estimated that the breakdown in effort and costs of the entire project by stage were: planning, $12 \%$; operations, $76 \%$; and post-eradication monitoring, $12 \%$.

\section{Discussion and conclusions}

The NPS and WS made a planned and sustained effort to eradicate the introduced roof rats from Buck Island from 1998 to 2000 . The rats were causing substantial damage to a variety of the island's floral and faunal resources (National Park Service 1999). Wildlife Services established an island-wide grid of elevated bait stations and used anticoagulant $(0.005 \%$ diphacinone, $50 \mathrm{ppm}$ ) rodenticide bait blocks to eradicate the rats. The bait stations were modified several times to assure ready access by rats while minimising access by non-target animals. Several years of post-project rodent surveys resulted in no rat captures, suggesting that, indeed, the rats had been eradicated from Buck Island. Field personnel observed no non-target losses as a result of the baiting program. No predation on sea turtle nests has been observed since the eradication. Field personnel have also noted what appears to be a recovery of many of the island's other natural resources, both floral and faunal, although this recovery was not quantified. Additionally, identifying the causal factor(s) in floral and faunal resource recovery can be very difficult because the influence of many confounding factors on tropical islands such as drought, hurricanes, other invasive species, and management activities.

It appears that all the objectives of this project have been achieved. The rats have been eradicated and rat predation on sea turtle nests has been eliminated. The island may now be used as a reintroduction site for the endangered St Croix ground lizard because rat predation will not occur nor will rats compete for food resources used by the lizards. The disease threat posed by rats and their ectoparasites has been eliminated. It is also suspected that the public and agency awareness of threats posed by exotic, introduced species has been heightened by the press 
releases, processes, and outcomes of this project. A post-eradication rodent-monitoring protocol has been implemented.

Post-project surveys revealed the presence of a growing house mouse population (another introduced species) on the island. According to previous sightings, this species may have been present all along, but its population and activity was perhaps greatly suppressed by the rats. Removal of the rats allowed the house mouse population to flourish in what can be described as a 'competitor release' effect (Caut et al. 2007). Introduced house mice are common on many of the islands and cays of the Caribbean (Dammann and Nellis 1992). They can cause considerable damage to vegetation and predation on eggs, birds, and lizards, although probably not as severe as that caused by rats (Newman 1994; Miller and Miller 1995; Key et al. 1996; Cuthbert and Hilton 2004). Introduced house mice can also impact invertebrate populations (Le Roux et al. 2002; Smith et al. 2002).

Although we determined that the house mice did not survive the eradication project because of genetic resistance to diphacinone, other possibilities might explain the result. For example, it is possible that the elevated bait stations were not accessible to the mice or that rat activity and the small home ranges of the mice (relative to rats) precluded access by many mice to the 40 $\mathrm{m}$ by $40 \mathrm{~m}$ island-wide bait station grid set for rats. Because house mice are known to jump as high as $40-45 \mathrm{~cm}$ (Baker et al. 1994) and, hence, could have accessed our elevated bait stations, we presume that the bait stations were too far apart to provide access to one in each house mouse territory. Making the rodenticide bait available to every individual of the targeted species at risk is a key component of a successful eradication strategy (Parkes and Murphy 2003). Had we known that mice might become a problem on the island, we could have designed our approach differently. For example, bait could have been broadcast over the island for more complete coverage, or the bait stations could have been placed closer together. Eradication of house mice can be difficult and reinvasion (often in cargo) is likely (Burbidge and Morris 2002). Nonetheless, the successful eradication of introduced house mice from islands has been accomplished on at least 20 occasions (Howald et al. 2005b). The threats posed by, and potential management strategies for, this invasive rodent species on Buck Island are being assessed by the NPS to determine whether a management plan should be implemented.

A rat eradication will be successful in the long term only if protocols are in place to prevent the reintroduction of rats to the island. The NPS has implemented regulations for the public to help reduce the probability of a reintroduction: boats must be anchored offshore, use of the small NPS pier is limited to drop off and pick-up only, picnicking parties are to remove all trash when they leave the island, no overnight camping is allowed on the island, a semi-annual rodent survey is conducted, and a public education program emphasises the damage caused by introduced rodents. Enforcement of these regulations, however, continues to be problematic for a NPS unit with limited staff.

Since the Buck Island rat eradication, we have used the same methodology on three other small islands in the US Virgin Islands: Dutchcap Island (12.9 ha) north-west of St Thomas Island, Saba Island (12.3 ha) south-west of St Thomas Island, and Congo Island (10.6 ha) north-west of St John's Island. At least two rat-trapping sessions have been conducted on each of these islands with no rat captures (Pierce 2004). While this suggests that the rats have been eradicated from those islands, further monitoring is necessary for confirmation.

We believe that the Buck Island project is the first documentation of a successful eradication of rats from a sizable island using diphacinone bait blocks in elevated bait stations. This approach, however, requires considerable time, labour, and resource investment. An interagency effort in the United States is currently pursuing national registrations with the EPA that would allow broadcast-baiting (including aerial application) with diphacinone pellets as well as brodifacoum pellets for use on introduced rodent populations on conservation lands. Aerial broadcast baiting can greatly improve the efficiency and likelihood of success of eradication of rodents from islands (Howald et al. 2005a). Whereas brodifacoum has been proven effective in rat eradications, diphacinone provides an alternative to that highly toxic rodenticide and may help reduce non-target hazards in some situations, although several applications are generally required.

\section{Acknowledgements}

The rat-eradication project was conducted under Interagency Agreement No. 1443IA500009905 between the NPS and WS. We especially thank NPS Park Superintendent Joel A. Tutein for hosting WS and facilitating the work. NPS personnel, BrendaLee Phillips, Philippe Mayor and Kimberly Woody, assisted in many ways. Marianne Jensen, WS Budget Assistant, greatly assisted in the management of the project, personnel, and budget. Dr Earl Campbell, FWS (formerly with WS), provided useful advice on the project. The tireless efforts of WS field staff (Kelly Ladner, Chad Fuqua, Trae Noblett, Allen Gosser, Joyce Wakefield, Ashley Rossi, Pedro Quinones, Doug Hall, Ken Garner, Damon Hughes and James Rebholz) allowed the success of the project. We appreciate the review comments of Michael Fall, Susan Jojola and several anonymous reviewers.

\section{References}

Atkinson, I. (1985). The spread of commensal species of Rattus to oceanic islands and their effects on island avifaunas. In 'Conservation of Island Birds'. (Ed. P. Moors.) pp. 35-81. International Council of Bird Preservation, Technical Publication No. 3.

Baker, R., Bodman, G., and Timm, R. (1994). Rodent-proof construction and exclusion methods. In 'Prevention and Control of Wildlife Damage'. (Eds S. Hygnstrom, R. Timm and G. Larson.) pp. B-137-B-150. (Cooperative Extension Service, University of Nebraska: Lincoln, NE.)

Billing, J. (2000). The control of introduced Rattus rattus on Lord Howe Island: the status of warfarin resistance in rats and mice. Wildlife Research 27, 659-661. doi:10.1071/WR99013

Billing, J., and Harden, B. (2000). Control of introduced Rattus rattus on Lord Howe Island: the response of mouse populations to warfarin bait used to control rats. Wildlife Research 27, 655-658. doi:10.1071/ WR99012

Buckle, A., and Fenn, M. (1992). Rodent control in the conservation of endangered species. Proceedings of the Vertebrate Pest Conference 15, $36-41$.

Burbidge, A., and Morris, K. (2002). Introduced mammal eradications for nature conservation on Western Australian islands: a review. In 'Turning the Tide: the Eradication of Invasive Species'. (Eds C. Veitch and M. Clout.) pp. 64-70. (International Union for the Conservation of Nature, Invasive Species Specialist Group: Gland, Switzerland.)

Caut, S., Casanovas, J., Virgos, E., Lozano, J., Witmer, G., and Courchamp, F. (2007). Rats drying for mice: modelling the competition release effect. Austral Ecology 32, in press. 
Courchamp, F., Chapuis, J.-L., and Pascal, M. (2003). Mammal invaders on islands: impact, control and control impact. Biological Reviews 78, 347-383. doi:10.1017/S1464793102006061

Cuthbert, R., and Hilton, G. (2004). Introduced house mice Mus musculus: a significant predator of threatened and endemic birds on Gough Island, South Atlantic Ocean? Biological Conservation 117, 483-489. doi:10.1016/j.biocon.2003.08.007

Dammann, A., and Nellis, D. (1992). 'A Natural History Atlas to the Cays of the U.S. Virgin Islands.' (Pineapple Press, Inc.: Sarasota, FL.)

Donlan, C., Howald, G., Tershy, B., and Croll, D. (2003). Evaluating alternative rodenticides for island conservation: roof rat eradication from the San Jorge Islands, Mexico. Biological Conservation 114, 29-34. doi:10.1016/S0006-3207(02)00401-9

Eason, C., and Spurr, E. (1995). Review of the toxicity and impacts of brodifacoum on non-target wildlife in New Zealand. New Zealand Journal of Zoology 22, 371-379.

Eason, C., Murphy, E., Wright, G., O'Connor, C., and Buckle, A. (2001). Risk assessment of broad-scale toxicant application for rodent eradication on islands versus mainland use. In 'Advances in Vertebrate Pest Management II'. pp. 45-58. (Filander Verlag: Furth.)

Flanigan, T., Schwan, T., Armstrong, C., Van Voris, L., and Salata, R. (1991). Relapsing fever in the U.S. Virgin Islands. Journal of Infectious Diseases 163, 1391-1392.

Furniss, S. (1984). 'Recovery plan for the St. Croix ground lizard, Ameiva polops.' (United States Fish and Wildlife Service: Atlanta, GA.)

Genovesi, P. (2005). Eradications of invasive alien species in Europe: a review. Biological Invasions 7, 127-123. doi:10.1007/s10530-0049642-9

Hadler, M., and Buckle, A. (1992). Forty five years of anticoagulant rodenticides - past, present and future trends. Proceedings of the Vertebrate Pest Conference 15, 149-155.

Hosea, R. (2000). Exposure of non-target wildlife to anticoagulant rodenticides in California. Proceedings of the Vertebrate Pest Conference 19, 236-244.

Howald, G., Mineau, P., Elliott, J., and Cheng, K. (1999). Brodifacoum poisoning of avian scavengers during rat control at a seabird colony. Ecotoxicology 8, 431-447. doi:10.1023/A:1008951701780

Howald, G., Faulkner, K., Tershy, B., Keitt, B., Gellerman, H., Creel, E., Grinnell, M., Ortega, S., and Croll, D. (2005a). Eradication of black rats from Anacapa Island: biological and social considerations. Proceedings of the California Islands Symposium 6, 299-312.

Howald, G., Samaniego, A., Tershey, B., Pyle, P., Buffa, J., Keitt, B., and Jones, H. (2005b). Options for removing house mice from the Farallon Islands, Farallon National Wildlife Refuge. (Island Conservation and Ecology Group: Santa Cruz, CA.)

Innes, J., and Barker, G. (1999). Ecological consequences of toxin use for mammalian pest control in New Zealand - an overview. New Zealand Journal of Ecology 23, 111-127.

Key, G., and Hudson, R. (2000). The rat control program on the island of St Helena. Proceedings of the Vertebrate Pest Conference 19, 133-138.

Key, G., Platenberg, R., Easby, A., and Mais, K. (1996). The potential impact of introduced commensal rodents on island flora. Proceedings of the Vertebrate Pest Conference 17, 172-178.
Le Roux, V., Chapuis, J.-L., Frenot, Y., and Vernon, P. (2002). Diet of the house mouse (Mus musculus) on Guillou Island, Kerguelen Archipelago, subantarctic. Polar Biology 25, 49-57. doi:10.1007/s003000100310

Lorvelec, O., and Pascal, M. (2005). French attempts to eradicate nonindigenous mammals and their consequences for native biota. Biological Invasions 7, 135-140. doi:10.1007/s10530-004-9643-8

Meier, A., Noble, R., and Zwank, P. (1990). Criteria for the introduction of the St Croix ground lizard. New York State Museum Bulletin 471, 154-156.

Miller, C., and Miller, T. (1995). Population dynamics and diet of rodents on Rangitoto Island, New Zealand, including the effect of a poison operation. New Zealand Journal of Ecology 19, 19-27.

Murphy, E., Clapperton, B., Bradfield, P., and Speed, H. (1998). Brodifacoum residues in target and non-target animals following largescale poison operations in New Zealand podocarp-hardwood forests. New Zealand Journal of Zoology 25, 307-314.

National Park Service (1999). 'Island-wide Rat Eradication Environmental Assessment.' Buck Island Reef National Monument, Christiansted, St Croix, VI.

Newman, D. (1994). Effects of a mouse, Mus musculus, eradication programme and habitat change on lizard populations of Mana Island, New Zealand, with special reference to McGregor's skink, Cyclodina macgregori. New Zealand Journal of Zoology 21, 443-456.

O'Connor, C., and Eason, C. (2000). Rodent baits and delivery systems for island protection. Science for Conservation 150 [New Zealand Department of Conservation: Wellington.]

Parkes, J., and Murphy, E. (2003). Management of introduced mammals in New Zealand. New Zealand Journal of Zoology 30, 335-359.

Philobosin, R., and Ruibel, R. (1971). Conservation of the lizard Ameiva polops in the Virgin Islands. Herpetologica 27, 450-454.

Pierce, J. (2004). Control of non-native species at USVI offshore islands. US Fish and Wildlife Service, Region 4, Atlanta, GA.

Shore, R., Birks, J., and Freestone, P. (1999). Exposure of non-target vertebrates to second-generation rodenticides in Britain, with particular reference to the polecat Mustela putorius. New Zealand Journal of Ecology 23, 199-206.

Smith, V., Avenant, N., and Chown, S. (2002). The diet and impact of house mice on a sub-Antarctic island. Polar Biology 25, 703-715.

Tasheva, M. (1995). 'Anticoagulant Rodenticides.' (World Health Organization: Geneva.)

Veitch, C., and Clout, M. (2002). 'Turning the Tide: the Eradication of Invasive Species.' (International Union for the Conservation of Nature and Natural Resources: Gland, Switzerland.)

Witmer, G., Campbell, E., and Boyd, F. (1998). Rat management for endangered species protection in the U.S. Virgin Islands. Proceedings of the Vertebrate Pest Conference 18, 281-286.

Witmer, G., Martins, H., and Flor, L. (2004). Leptospirosis in the Azores: the rodent connection. Proceedings of the Vertebrate Pest Conference 21, 217-220.

Manuscript received 11January 2006, accepted 19 February 2007 